ful look of returning health and rescued life and that inward satisfaction which far surpasses all the weal th of the Orient-" "Inasmuch as ye have done it unto one of the least of these, my hrethren, ye have done it unto Me."

\title{
A CONTRIBUTION TO THE SURGERY OF THE KIDNEY AND OF THE URETER.'
}

\author{
By Arpan G. Gerster, ar.D., \\ OF NET YORK.
}

Dunisg the period heginning June 21, 1895, and ending February 1,1897 , thirteen patients suffering from various affections of the kidney and of the ureter came under the vriter's care at Mount Sinai Hospital.

\section{Ureters.}

In four cases causative affections of the ureters were ohserved. In three of them the trouhle was relieved permanently hy operative procedures which were hased upon the lahors of Küster, Fenger, and Howard Kelly.

CASE I. Hydronephrosis of traunatic origin; nephrotomy, followed by successful plastic of the proximal orifice of the ureter; cure. -J. W., aged nine years, a well-developed, hut somewhat emaciated hoy, had sustained a severe contusion in January, 1895, while coasting on the snow. Hicmaturia followed and persisted for nearly four weelis. Nuch pain was complained of also, accompanied hy considerahle fever, which, however, ahated by the end of the third week. Ahout six months later a peculiar scoliotic posture was ohserved in the hoy, which was found to he dependent upon the presence of a tumor located in the right hypochondrium. About two quarts of urinous fluid were withdrawn from this tumor, and the following Decemher three pints were again removed. On January 31, 1896, the following conditions were found : in the right hypochondrium, extending well hack into the loin, a large fluctuating tumor; the colon could he determined, hoth hy percussion and palpation, situated below and in front of this tumor. The urinary examiuation yiclded a normal result, specific gravity 1020 . The liquid ohtained hy puncture was clear, straw-colored, and charged with urinary contents. On Fehruary 3d, chloroform heing administered, the tumor was exposed hy an ohlique lumhar incisiou, whereupon, the reflection of the peritonenm heing found, this was stripped up until the ureter was exposed. Now the sac was freely incised and evacuated. The attenuated substance of the kidney represented in the plane of section a crescent-like mass ocenpying the upper and posterior part of the periphery of this sac, having in its middle the thickness of ahout an inch. On the inner surface of this mass unchanged renal papilla could he

1 Read before the society of the Phrsiclans of the German Dlspensary, New York, February, 24, 1897.

YoL. 119, No. 6.-SUNE, 1897. 
easily recognized. No sacculation of tho calices tras present. Tho proximal orifice of the areter was very conspicuous, nod was found on the noterior wall of tho eae ahout three inches ohore that part which would he its hottom in the upright posture. It resemhled a aippleshaped elevatioa projecting about one-third of an iach into the lumen of the soc. (Fig. 1.) Tho crerted mucous memhrane of the ureter was

Fo. 1.

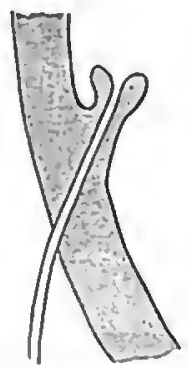

Lopstludinal acetioo of renal ordifee of uroter.

thickeped, hypersemic, and hled on touch. A silver probe wns arrested at about the base of this projection, hut the resistance yielded to moderate pressure, whereupon an elastie hougie (Tio. 5, Frewch measure) was readily passed in to the hlodder. By the time these facts were ascertajaed the boy's pulse hecame thready, wherefore, after being plugged, tho sac was attached hy $n$ few gutures to the interumeat, and tho wou ad was iressed. The boy rallied promptly on stimulation, and only moderate fever followed. During the first treaty-four hours ono and oaelnalf piats of uriae were passed hy the urethr. Heace, it could he assumed that the left kjdney acted in a satisfactory manner.

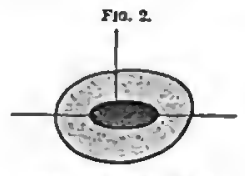

trederes of ureveral ortace.

On Fehraary Gth chluroform vas administered again, and the orifice of the ureter heing exposed, the following plastic operation was performed: the everted rim of the orifice of the ureter was inciead on the right and on tho left side, as trell as in the middle of the upper circumference, tho incision being carried far enough down wned into the ureter to divido the strieture, also, at three poiats. (Fig. 2.) The upper 
nad lower nngles of each of these rhomboidnl wounds were sutured with catgut-i.e., the longitudinal incisions were sutured transtersely (Fenger). It became evident now that the lower portinn of tho projecting rim also needed a plastie correction. Accordingly a finp of mucous membrane one-third of an inch wide nnd three-quarters of an joch long and distant from tho ureter nbout one-half na inch, was exeised from the lining of the sac, the defeet being united by five buried catgut sutures. (Fig. 3.)

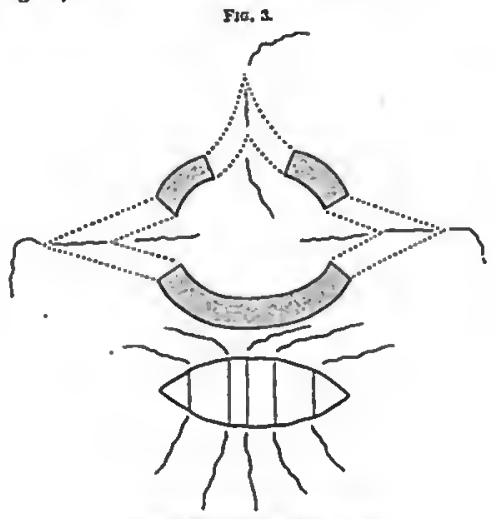

Ihulle of reas ortece of treter.

By this lnst step the nippleshnped prominence was converted iutn a shallow, funnel-shaped depression An elastic eatheter baving been placed into tho ureter, the wound ras lightly plugged and dressed. Slight reaction followed, and blood was ahserved shortly after the operation in tho urine vaided from the blndder.

On the morning of Fehruary 7 th the entheter had to be removed from tho ureter on nccount of severe pains mdinting taward the bladder and penis. On Fehruary 9th the tamponade was renewed. On Feb. ruary 16 th the dischnrge hecame slightly purulent, with moderato ferer. On account of this compliention plugging was discontinued, and two stout rubber drainge-tubes rere inserted, by means of which the sac wns irrigated three times a day with boro-salicylic solution. At the end of each of these irrigations a small quantity of methylene-hlue was ndded to the solution to test tho permeahility of the ureter. By Fehruary 20th methylene-hlue staining of the urine roided from the bladder was first observed. There was moderate fever every eveoing until the end af February. On March 1st the gaping round was partinlly elosed by menns of a number of silkwarm. gut stitches passed through tbe parenchyma of the kidney, leaving an aperture just suffciently lange for the drainage-tubes.

From this time an the boy picked up gradunlly, lenving the bed an 
March 7th, and on March 15th he wras sent home to Vermont, with instructions to have tbe sac irrigated daily. As there was considerahle wetting from the renal fistnla, a generous moss cushion was applied over the ordinary dressing, by which most of the urine was absorbed.

On April 15th the following report renched me by letter: "There was considerahle fever, rising up to $103^{\circ} \mathrm{F}$, after the hoy's arrival from New York, which, however, ahated as soon as the sac was properly irrigated. Thereupon the nppetite returned, and the hoy commenced to gain flesb nnd strength. At present there is very little discharge from the drainage-tube. The hoy voided nbout a quart of urine by the hladder, which is acid and contains small quantities of pus."

On Mlay 3d the patient was presented nnd looked excellently well. I found in the renal fistuln a small drainage-tube, the moss cushion nearly dry. The capacity of the sac was ascertained to be one and one-balf ounces by measure. Methylene-hlue found its why immediately to the bladder. The urine ras found to be normal, with tbe exception of microscopic quantities of pus. I decided to remove the drainage-tube tentatively. By July the fistula was reported closed, and the hoy perfectly well. 1

CASE II Hydronephrotic floating kidney; nephrectomy; cure.-Mrs. T. R., aged twenty-fire years, nulliparn, stated that on December 1, 1896, sbe began to suffer from paroxysmal pains of the left loin, without $n$ known cnuse, requiring the administration of morpbine. Tbe paroxysms bewme milder nnd rarer, but tbe paticnt lost flesb, and was distressed by $\mathrm{n}$ censeless, dull acbe, seated in the left loin, and radiating townd the corresponding groin and femur. A few weeks before this a large lumbar swelling was found by Dr. Paul F. Munde, who sent the patient to me. The tumor was ahout the size of $n$ cbild's head, Tas very movable, smootb, not painful on pressure, nad very tense, so that fluctuation became apparent only after puncture, which yielded $n$ clear, colorless serum, with only traces of urinary contents. Tbe patient baving been ndmitted to Mount Sinni Hospital, the daily amount of urine voided by the urethra was ascertaned to he nbont tbree pints, of normal quality. Hence it was apparent that the other lidney acted properly. The alternative was either to remove the sac or to attempt the restoration of the function of the ureter, which had been lost through $\mathrm{n}$ cause is yet to be ascertained. Tbe matter being laid before the patient, gbe was told thnt the former procedure would, in all probability, yield n mpid nnd complete cure, whereas tbe latter plan was not so certain in its results, and would require prolonged trentment, and possibly repeated operations. The patient declined any experimental measures, insisting upon the summary proceeding. On December 2, 1896, calomel was sdministered, followed hy salts, causing n number of copious evacuations. The next morning the tumor had disappeared, and only when the patient had heen ansesthetized with chloroform, on December 4th, could in flabby, ill-defined mass he felt nt the site of the tumor. This was displaced well backward toward the loin hy pressure exerted hy nn assistant's hand, and was exposed hy the

1 On March 11, 1897, the patlent presented himscif with renal fistula reopened. The pelrls held one and one-half ounces of fiuld. The colored fluld, howerer, did not descend promptly to the hladder; hence we concluded that a recontractlon of the renal apertare of the ureter had taken place, which will need further correction. 
usual oblique iacision. It was seen to coasist of a much-disteaded kidney and its pclvis. It was very readily stripped out of its fatty capsule and withdrawn from the envity, which was a very easy matter on account of the loag pedicle. The pedicle heing now compressed, the pelvis of the hidney was laid open hy an in cision carried freely through the attenuated cortex. Within the distended pelvis the entrance to the ureter was easily found, and appenred to bc normal. The ureter was patulous throughout. Hence the hydronephrosis was due to ohstruction by flexion. The kidaey itself presented a characteristic example of what Feager describes as sacculated cystonephrosis. Fach calix was mucl distended, communicating hy a narrow orifice with the pelvis of the kidney, so that the mass really consisted of a number of smaller sacs communicating with the larger eavity of the pelvis. Feager had succeeded in curing a similar ease hy operation. He split tbe kidaey ia two longitudiaally. Tbe profuse hemorrbage proceediag from the large braacbes of tbe reaal artery ruaaiag through the septa was controlled by continuous suture. The septa separating the caliees from the pelvis were severally divided. In this, our case, the correction of the sacculatioa would have aceded the complement of $a$ repair of the defective ureter-i.e., a portion of its proximal ead rould have been excised so as to shorten and stretcb it, to prevent folding upon itself. Finally, the shortened ureter would have been implanted into tbe deepest part of the renal pelvis, as was done successfully by Kuister. In view of the uavilliagness of tbe patient, we bad to abandoa this eaticiag plan, and the kidaey was accordiagly removed. The ureter and veasels were severally tied with catgut. A drainage-tube was placed into the bottom of thc wound, most of which was closed by suture. There was an uneveatful recovery, the patient beiag discharged cured December 30th.

It must be considered a decided advance in the rigbt direction tbat the cure of bydronepbrosis caused by obstructions in tbe ureter, or the pelvis of the kidney, or the elimination of renal fistuln, is aor attempted in a conservative manner ratber than by the sacrifice of tbe kidaey, which procedure begins to appear ratber barharic. However, it must be added that external coasiderations, as, for instance, the cboice of tbe patieat, or a dangerous collapse caused by hemorrbage or heartfailure, may still and will compel the surgeoa occasioally to have recourse to the summary process of nephrectomy, whicb, after all, yields a rapid and certain result. Under circumstances similar to those here related was I compelled to remove an otherwise healthy kidney in Fehruary, 1895, at the German Hospital. The case is reported in the Annals of Surgery for January, 1896.

CASE III. EInpyema of the ureter after nephrectomy; extirpation of the ureter; cure.-J. $\overrightarrow{\mathbf{K}}$, aged tweaty-six years, photographer, sustained duriag his twelfth year a severe compound injury of tbe left upper extremity, followed hy suppuration and great deformity. In tbe summer of 1893 nephrotomy was performed on him for pyonepbrosis by Dr. Park, ia Buffalo, and the kidney heing found to he totally dísintegrated it was immediately removed. A rebellious fistula persisted, which closed from time to time. Wbenever this occurred 
symptoms of fever and retention supervened, which abatcd only after perforation and evacuation of the lumbar abscess. He was admitted to Mount Sinai Hospital in July, 1896. Considerable pyuria and nn abscess of the prostate were found. This heing incised, tbe pyuria still continued. Cystoscopy was impossible on necount of n tight stricture of the prostatic uretlira. In tbe left loin a very deep sinus was seen passing from the centre of the old senr downwned and forwnrd, and discbarging from time to time large quantities of pus. No tumor could be felt in the hypocliondrium. It was suspected that the discharge might be due to a retained ligature, wherefore tlie cicatrix was extensively Iaid open, but no ligature could be found. The Inrge wound was packed, and as the wound was beginning to contract a remarkable variation in the nmount of the discharge was observed. Wbenever the silus was discharging copiously the urinc became nearly normnl, but when the lumbnr sinus hnd contrncted largn quantities of pus appeared in the urine. This nlternntion mnde it. evidcnt that the suppnration must be due to a disensed coadition of the ureter. The wound in the perineum healed very slowly, closing by the middle of Octoher. Oa November 13 th we proceeded to extirpate the ureter. The most difficult portion of the task was the fiading of the renal ead of the ureter, which was searched for in a large cicatricial mass closely conaected witb the peritoneum. I decided aot to work ut random, but to proceed systemntically, my plas being to find tlie reflection of the peritoneum and to follow this toward the spinal columa, gradually raising the peritoneum from the cicatrix until the ureter wns found. This plan proved to be successful. An oblique iucision follorsing the old scar, and contiauing beyoad it far enough formard, was passed through the abdominal muscles uatil the peritoneum was exposed in the anterior angle of the wound. This being stripped up, the posterior aspect of the descending colon hecame visible. Where the cicatricial mass commenced the peritoaeum was dissected up with the knife carefully and slowly, the dissection progressing toward the median line. While tbus proceeding, on account of the unyielding cicatricial deposit, the space became somewhat cramped, wherefore a second vertical incision, running parallel and close to the murgin of the quadratus muscle, was added. This liberated the tissues to sucb an extent that the ureter was soon exposed. Its renal orifice was recognized by the everted byperxemic mncous mombrane. From this point on the operation became very easy. The peritoneum was stripped up along the downwnrd course of the nreter. We found Cnhot's statement beautifully verified, tbnt on raising the peritoneum the adberent ureter would follow it. The oblique incision was furtber extended downward, nnd afterward to Poupart's ligament, care being taken to leave a sufficient muscular mass attacbed to the rim of the os ilium to enable us to apply an abdominal suture. Successively the psons major . and minor muscles, then tbe iliac vessels, were exposed, and the ureter was separnted from its peritoneal adbesions. The vas deferens could not be seen. The lower portion of the ureter was found to be distended, its diamcter being nearly three-fourths of an inch, its lining very tumid and strongly injected. It contained a Inrge quantity of pus, which welled up unexpectedly, flooding the field of operation. Close to the bladder tbe ureter was found to be very brittle, and a continuous dissection became impossible. On attempting to pass a sound into the 
bladder it was found that in close proximity to the lower orifice of the ureter a stricture existed, which, bowever, permitted tbe passage of an ordinary silver probe. The ureter was removed close to tbis stricture, its estimated distance from the bladder being not more than an iach. The wound was now tboroughly cleansed by irrigation, nad its middle portioa beiag closed by a dozen stout silkworm-gut button sutures, the upper and lower angles rere drained nnd left open. Tbe procedure had consumed about two bours, and the patient bad become very weak. The small and rapid pulse did aot respond promptly to eaergetic stimulatioa, and the patient's coadition remained critical ior forty-eight bours. Profuse sweats, coatiauous romitiag, cold cxtremities all bode evil, nnd could aot be ascribed to los3 of blood, which had beea moderate, but had to bc rather cbarged to the extengive stripping up of the peritoaeum. Finnlly the pulse improved, the patient's temperature risiag from subnormal to $101^{\circ} \mathrm{F}$. Lively suppuration followed from the bottom of the enormous wouad, hut the draiage was adequnte nad tbe alodomianl suture healed tbroughout by first iuteation. The upper angle healed first. It took about four weeks to bring about closure of the eatire wouad. To earble us to deal with the paticat's cystitis the urcthral stricture was gradually dilnted, and tbe bladder frequeatly irrigated. On January 22, 1897, a cystoscopic examination was made. It wns found that tbe orifice of the right ureter was aormal, tbat of the loft ureter being difficult to locate in the mass of hyperemic ridges of mucous membrane. Gradually the cystitis also yielded, and tbc patient, formcrly sufferiag from rery frequeat uriaation, can at present hold his water for two hours. His geacral coadition bas improved woaderfully, and he is still gaiaing weigbt. The patient was thereupon preseated for inspection.

Pertaiaing to this subject is tbc observation that ccrtain forms of pyelitis are maintained by temporary causes, which are very often relieved as soon as the pelvis of the kidaey is drained through a direct incision made from tbe loia. A clot of blood or fibria, or a calculus, may be the eause of such transient disturbance. In tbe fall of $1894 \mathrm{I}$ had occasion to test tbis method of treatmeat in a case of acute pyelitis witb evideat reteatioa. After maintaiaing draiange for about four weeks the fcbrile symptoms disappeared, aad the drainage-tube being withdrnwn the wound healed, tbe patient making a perfect recovery. In tbe following case, however, tbe relief was temporary only, lastiag so loag as the renal fistula was open:

CASE IV. Double pyelitis, with intense cystitis; nephrotomy of the left side; temporary improvement.-MIre. G. Z., aged thirty-eight years, multipara, had beea sufferiag for three yenrs with rery painful urinntion. The uriae, voided in small quastities, was turbid and very oftea, townrd the ead of micturition, tinged witb blood. For two months sbe complaiaed of frequeat attacks of lumbar pain. The robust woman was admitted to tbe bospital March 3, 1896, and her physical coaditioa was found to be otherwise sound. Oa cystoscopy, according to Kelly's method, tbe bladder was fouad to be extremely irritable, its mucous membrane everywhere velvety, bleediag on touch. The trigo- 
num, especially, was found to he much injected and intumescent, so that the left ureter could not he found. Catheterism of the right ureter, however, was accomplished, and twenty-eight grammes of a moderately turbid, acid urine rere secured, which contained fers pusand hlood-corpuscles, specific gravity being 1024. The kidneys could not he felt hy palpation, hut intense pain rras complained of on pressure exerted orer the left lumbar region. The pntient voided forty-one ounees of urine from the 3d to the 4th of March. Diagnosis was made of douhle pyelitis, with chronic cystitis. The bladder would not lold more than two and one-hnlf ounces of fluid during deep anastliesin. On MLarch 26th the left kiduey was exposed. The aspirating-needlc witbdrew from the pelvis ahout two ounces of slightly turhid urine. Hence it was fnir to conclude that it was somewhat distended. Along the aspirating-needle the pelvis of the kidney was freely incised, the incision heing carried through the convexity. The surface of the kidney, as well as the pareuchyma, appeared normal. Little reaction followed, the frequent urgency to urination hecoming decidedly diminished, presumahly in proportion to the reduced quantity of urine passing out through the bladder. A pril 1st cystoscopy was repeated, and the condition of the interior of the bladder was found unchanged. April 21st the patient was discharged at her own request, with the advice to wear a drninnge-tuhe for several months. The disagreenble vetting of her clotbiag caused by the renal drainage, horrever, discouraged her so soon that she had the tube withd mwn by the end of MLay, wbereupon tbe fistuln closed within a very short while. There reas a strong suspicion of tuberculosis, which, howerer, could not be coafirmed, though frequeat search for Koch's bacilli was institutel. Inoculation of a rabbit with the urinary sediment yielded also a negative result.

\section{Echinococcus of the Kuiney.}

It is well known that the kidney bccomes very rarely the seat of hydatids. Statistics show that the left kidney is about twice as often attacked as the rigbt. The literature of the subject, comprising over three hundred recorded cases, containg only one instance of calcification of the sac. In Simon's case (No. 6) partinl calcification is mentioned, wherens in this, our case, the entire sac was calcified throughout.

Echinococcus of the right kidney; hydatids voided by the urethra; exposure of the large tumor; incision and evacuation of the contents of the calcareous sac; secondary extirpation of the concremental shell; cure.Mrs. E. D., aged twenty-six years, was presented by Dr. Steudel, of Seymour, Conn., June 19, 1895. The delicately huilt, small woman was pregnant in the sixth month, and stated that up to within three months she had felt entirely wcll, with the exception of a dull and heavy feeling she had observed to exist in the rigbt hypochondrium for about seven years, which, however, had caused her no serious inconvenience. She said that eight years ngo, while serving in a place in Germany, she had to feed regularly a numher of dogs. A fortnight ago she was attacked hy severe renal colic while voiding urine, and she ohserved that toward the end of micturition a numher of grape-like hodies passed away from lier. A collection of these bodies was shown to me, 
which I immediately recognized as secondary hydatids. Dr. Steudel also found a considerable tumor in the right loin, which on examination was found to he smooth, unustally resistant, non-fluctuating and immovahle. It extended downward in the right hypochondrium to the level of the navel, but was not influenced hy the respiratory movements. Corresponding to the lovermost portion of the mass a smaller, knob-like, softish projection could he felt, which was very tender on pressure. By percussion it could he ascertained that the tumor extended upward to the level of the seventh rib posteriorly. Moderate nightly elevations of the temperature were ohserved, on account of which circumstrnce $I$ advised nn operation. Being ndmitted to the hospital, her daily quantity of urine was found to be 1430 grammes. It contained neither albumin, pus, nor sugar. All other organs were found normal. On June 21st, the patient heing chloroformed, the tumor was exposed by an ohlique lumhar incision. Now it hecame evident that the knoh-like projection found on the lower circumference of the mass cousisted of ahout two-thirds of the normal kidney, upon the upper pole of which, and conneeted with it, rested the large ovoid tumor, having the shape and size of a small coconnut. The attempt to puncture the tumor failed because a stout ncedle could not he forced into it, hreaking off. Finally, with considerable trouhle, a square aperture was cut into the bony investment of the tumor hy means of a stout resection-knifc. Besides a small quantity of turhid serum, the cavity contained nothing hut a closely packed, nested mass of hydatid memhranes, cnclosed in a lnrge outer memhrane. All this material bcing scraped out with a sharp spoon, it was seen that the rough, hone-like shell was bleeding whercver scraped, hence it hecame clear that it was organized. The oozing was so considerahle that it hecame necessary to plug the cavity and to dress the wound. It may be added that the sharp spoon encountered everywhere the same resistance that an osseous cavity would offer to it. The place of communication hetrreen the hydatid cyst and the pelvis of tho kidney could not he found.

The operation was horne very well; hut in the course of the next week it hecame more and more evident that the cavity had not the slightest tendency to collapse and to diminish. It was clear that as long as the hard shell remained closure of the wound could not be expected. In Simon's case a number of small, bony plates were expelled, having apparently sloughed awny. In this our case, however, ve had to deal not with a rudimentary formation of small detached osseous plates, hut with a complete bone-like capsule of extremely hard material, which, as we anw Inter on, varied in thickness from hetween one-fourth to one-half of an inch, and was well vascularized everywhere. Hence it was not prohable that spontaneous expulsion would occur. As it is well known that the outer sac of echinococcus-cysts enters into intimate connections with all the organs of the vicinity, extirpation of the sac is rightly considered one of the most difficult undertakings, and was condemued as improper and inadmissihle hy Simon. In spite of these considcrations the contingencies of the case seemed to 
point urgently to the necessity of extirpation, which, with the consent of the patient, I determined to carry out.

On July 15th she was accordingly chloroformed. The operation was an exceedingly difficult, trouhlesome, and lahnrious one, both on nccount of the deep and inaccessible situation of a large part of the usteoid sac, and on account of the serious complicatinns which had to be encnuntered in the shape of the invasion of both the pleural cavity and the peritoneum. Twn of the lowcr rihs had to he excised, nnd even then the removal of the closely adherent calcareous masses wns very difficult, and hlunt dissection inapplicable. The edge of the knife had to he ised throughout. When the pleural cavity was widely opened alarming cyanosis and heart-failure set in. The pleural defect wns quickly plugged, and artificial respiration was instituted. After ahont five minutes the patient's condition had improved so far that the operation could he continued. It vas found that, just as on the plcural side, so toward the peritoneum the sac had incorporated the serous memhrane, and that a large portion of the peritoneum had to be taken away. As soon as the mass was detrched from the peritoneum the defect was closed with a catgut suture. The irregular-shaped, calcareous shells composing the entire capsule were of different sizes, the largest one mensuring over $7 \mathrm{~cm}$. in both directions; but most of them were mucl smaller aad were coarected along irregular lines hy short and dense connective tissue, resembliag the lines of cranial sutures in an infant's skull. Finally, after ahout two hours' hard work, all the calcareous masses wcre removed. The wound wns packed and the patient hrought to hed. Considerahle collapse followed aad had to be comhated hy frequeat stimulatioa, recurriag from time to time unexpectedly, so that coasiderable vigilaace had to be exercised. Finally, on the third day, the pulse was steadier and the patient's face lost the pinched look. On July 19th the packings were removed from the main cavity, and it became evident that this had contracted very considerahly. The pleural packings were removed oa July 21st, and from this date on progress Was steady and rapid until the middle of August, when the patient aborted, hut this did not retard her recovery long. Her gencral condition impmved steadily, nnd the large cavity contracted rapidly, so that the patient could he discharged cured, August 22d. Professor Simon mentions explicitly that in his case (No. 6) the extruded plate-like mass contained osseous tissue. In our case Dr. Schwyzer, pathologist of the German Hospital, found only calcareous matter. The remarkahle collection of potsherd-like concretions presented vividly recalls the shape of infantile cranial bones. The patient, also presented, is now perfectly well. On palpatinn the kidney can he felt connected with a resistant mass resting ahove it, which undnubtedly consists of shrunken cicatricial tissue.

\section{A Plea for an Earlier Performance of Nephrotomy in Anute Inflammatory Conditions of the Kidney.}

In the year 1890 a young woman was admitted to Mount Sinai Hospital with rebellious nnd rather profuse hrematuria, which was evidently of renal origin. No traumatism, no ncute malady had preceded, and the hemorrhage had persisted three weeks hefore the admission of the 
patient, who presented the signs of considerahle exsanguinatioa. Her spleen was not enlarged, the quantity of urine normal, its composition altered only inasmuch as it contrined $\mathrm{n}$ great deal of hlood and a few pus-corpuscles, which prohnhly came from the vagina. Every evening slight elevatioas of the temperature were ohserved, and the left kidney was rather sensitive botl on pressure nnd spontaneously, and sufficiently enlarged to be felt on palpatioa. I thought of the possibility of tuherculosis, calculus, or of a neoplasm of the kidaey. A numher of attempts were made to iaflueace the lemorrhage hy interaal medication, but were ineffectual. Finally the coadition of the roman hecame so alarmiag that $I$ decided to explore the kidney. Accordingly neplirotomy was done. It was found that the organ was considerahly enlarged aad turgid, and that the capsule was extremely tense. The kidney-fat was odematous. Punctures yielded a negative result. The capsule was incised along the entire convexity, whereupon the parenchyma of the kidaey hulged out somewhat. The capsule was strongly adhereat, and the surface of the kidaey marked hy a numher of puactate and stellate hemorrhages. By an incision carried through the convexity, the pclvis of the kidoey was opened, and, the left index-fiager heiag introduced into it, the eatire circumference of the organ was examined himanually. No stonc and no appreciahle tumor were found, and the pelvis gave the seasation of a normal mucous memhrane, A draiangetuhe was iatroduced, through which large quantities of hloody, urinous serum rere discharged. It was noted that the urine voided hy the urethra contained much less blood the day after the operation, and ia the course of the next tea days the hlood-stainiag of the uriae disappenred eatiraly. The local and general disturhances also disappeared, and a fortaight Iater the drainge-tube was withdrawn, whereupon the wound healed rapidly. I had occasion to see this patient in the year 1893 , when she told me that she had heen perfectly well ever since her last illaess. According to these facts, tuberculosis, neoplasm, and calculus could he positively excludel, it heing evideat that we had to denl with a form of acute nephritis nccompanied hy grent tensioa. The hyperamia gave rise to capillary hemorrhage, which was relieved hy the draiange and relaxation of tension afforded hy nephrotomy.

Within the last few years similar experieaces have heen noted by other surgeons, and fiaally there appeared in The Lancet, in its issue of January 4,1896, a communication hy Reginald Harrison, in which the iadication for the performance of nephrotomy is exteaded to some forms of acute alhuminuria which are aceompanied hy swelliag and tension of the kidaey. The following lines of thought will appear very natural to the surgeon who is accustomed to see the deleterious influence of great tension and infectious retention on various glandular organs. Every form of glaadular iafiammation, whether produced hy purely chemical or microhial, and through them iadirectly also chemical, influeaces, is accompanied hy proaounced disturhances of the circulation, which manifest themselves through the presence of hypersenia, stasis, exudation, and teasion. It is well known how favorahly the iaitial stages of these conditions are influenced hy a free incision, which 
rebeves tensioa. Especially noticeahle is this where glandular tissues are enclosed in a stout capsular envelope, ag, for instance, the testiclc, the suhmaxillary and parotid glnnds. In the case of the testicle and suhmaxillary salivary gland infection and excessive tension may lead to total necrosis, as can he seen in anginn Ludwigii and in cases of socalled spontaneous gangrene of the testis. As far as the final result is coacerned, it is not different whether the infection entered through the secretory ducts or through the circulation by cmbolism.

Very similar must he the coaditioas in the kidney. Total, emholic necrosis of the kidney, however, is an extremely rare occurrence, there heing only one case (Friedlander's) on record. The circumstance is explained hy the large size of the renal artery. But the destruction of multiple circumsarihed areas of the nrgan is a common ohservation. And where the integrity of the kidney is attacked through chemical influences circulating in the hlood we see that the secretory apparatus of the organ is prinarily attacked. If the invasion is a general one, we see that the disturhance is followed in its highest degrees by marked diminutioa in the urine, which becomes hloody and charged with alhumin, or fially by total and fatal suppression. Very often, in the primsrily nonfatal cases, lasting damage is doae. The destroyed secretory elements are not only not restored, hut their continued disappearnace will finally culminate in urrmia. Furthermore, the modifying influcace of purely mechanical interfereace with the normal circulation of the kidney by valvular lesions of the heart, or of a vicarious congestion due to sudden disahility of the other kidney, through traumatism, operation, or morhid procesies, will also have to he considered. Finally, as hefore stated, we have to mark the difference hetreen forms of nephritis cbaracterized hy rapid and extensive destruction noticenhle to the naked eye, and processes of degeneration which affect only the finer structure of the kidney. The questions which present themselves upon the hasis of these reflections are: First, Will the relief from tension afforded hy early nephrotomy nnd drainage exert $n$ favorahlc influence upon the initial stages of acute infectious processes nf the kidney, which otherwise would lead to suppuration? Secondly, Will nephrotomy exert a curative influence if it is performed during the initial hypercemic stage of certain forms of infectious, non-suppurative nephritis, which have a tendency to lead to ultimate loss nf the specific function of the organ, and are not relieved hy internal medication ?

Before answer is attempted to these questions we have to examine what danger is involved in the performance nf the operation of nephrotomy. We know that the relative danger of nephrotomy is directly proportionate with the extent $n f$ the renal damage. Tuffier (Duplay et Reclus, Traité de Chirurgie, tome vii.) gives a rate of mortality for nephrotomy performed in non-infectious cases of renal calculus of 6 
percentum; while in crses of pyonephrosis the rate for the same operation is 23.3 per cent. Other nuthors hnve arrived nt similar figures. My own statistics, embracing twenty-one nephrotomies, contain only one case of death following this operation, and in this case, as we shall see, the cause of death was really not dependent upon the operation. From this we see, then, thnt nephrotomy can he considered a comparatively safe operation. As a purely technical prohlem, nephrotomy is known to every surgeon to be, under ordinary circumstances, $n$ simple and easy procedure. The hemorrhnge unavoidnhly encountered is trifling and easily controlled, nnd the hemorrhnge caused by the incision of the rennl tissuc itself, though profuse nt first, is nlso easily checked by pncking. Should one or more of the larger branches of the renal nrtery, traversing the septa, he injured, the slight pressure exerted by a good pnck will nlwnys control the hleeding.

Let us return now to the questions which we have raised. To nnswer it in n categorical fashion, it is necessary to ascertain the degree of the injury sustained by the reual structures in each given case. The physical and chemical aids nt our disposal are extremely valuable aad important, but cannot yield the result thnt is gained from a systematic search made through the parenchyma of the kidney itself by the microscope. I consider Fenger's advice, to avail ourselves of each opportuaity afforded hy a nephrotomy to remove a segment of the kidaey for microscopical exnminntion, extremely useful. No harm is doas to the patient, and more definite and precise information is gained regarding the actual condition of the kidney thnn from the examination of the urine alone, which occasionnly lenves us in the lurch altogether. Momentous chnnges, as, for instance, capillary embolistn with consecutive infaretion, tho presence of pathogenic microbes in the primnry urinnry channels, desquamntive processes, and shrinkage of the glomeruli and canaliculi, can be positively recognized. In case of recovery their former existence cannot be gainsuid. As to the questions themselves, these answers can be given :

First, in all forms of suppurative inflammation of the kidney the surgicnl principle of early and extensive incision, to relieve tension nnd to afford drainage, is to he maintained with the same strictness nnd emphasis as it is accepted for all cases in which the suppurative focus is enclosed in rigid envelopes, cnpsules, fastive, or the periosteum. If a timely incision is not made, increasing tension will inevitahly end in the denth of the tissues. What we are nccustomed to do without hesitation in phlegmonous nffections of the suhaponeurotic tissues of the palm, in suppurations of the hurse, of the sahmaxillary and parotid glands, of the joints, nnd in acute infectious osteomyelitis-i.e., a free incision, should he done just as unhesitatingly in suppurations of the kidney. The ohjection that the diagnosis is difficult on nccount of the deep situation of the organ 
is not new. It had to he met, and was swept aside when the pathological conditions just mentioued were clearly recognized. With our ahility to diagnosticate deep-sented suppurations at an early stagc the hesitation formerly felt has disappeared. It is undouhtedly truc that in some of the most destructive iuvasions of the kidney, ns, for instance, in ascending septico-pyclouephritis, or in multiple embolic nephritis, onc or another or several of the important physical diagnostic signs may fail. But hy skilfully excluding all other organic disturhances, and in the presence of grave and threatening dnnger from suppression, the surgeon's action will he determined by weighing all the npparent circumstances. One of the most importaut and reliable signs of $\mathbf{n}$ serious involvement of the kidney is local pain on pressure. But even this symptom may he oceasionally nhsent, ns will he seen from the case puhlished hy Dr. Hornod Lilienthal, in Annals of Surgery, March, 1896, Case No. 3. The patient in question wns opernted on in the surgical division of MTount Sinai Hospital. The history is as follows:

Four weeks after an ncute osteomyelitis of the upper jaw, treated hy extensive incision and the extraction of a sequestrum, the course of healing having heen complicated by an attack of erysipelas, suddenly high fever developed with $\mathrm{n}$ rigor, nccompanied hy exquisite lumbar pain of the right side. The urine was normal, except thnt it contained a trace of alhumin, and micturition was painless. Guided hy the lumbar pain, Dr. Lilenthal incised, on MIny 5 th, a cortical ahscess of the right kidney. The sepsis continuing, another abseess was found on May 20 th hy an exploring-needle, and wns also iucised. At this time the urine was still free from pus, containing only a trace of alhumin nad a few blood-corpuseles, together with in few granular casts. The sepsis still continued, the patient losing ground visibly. He was delirious and somnolent. On July 10th I examined the patient with Dr. Lilienthal. He was extremaly emaciated, and presented the features of the gravest septico-pyamin. A thorough examination of all the internal organs evinced nothing positive. No pain on pressure could he found anywhere. In spite of this, and on nccount of the nhsence of other organic changes, I advised a renemed exploration of the right as well ns an incision of the left kidney. Accordingly, on July 23d, Dr. Lilienthal incised in hoth kidneys n number of cortical ahscesses. The patient recovered nnd was discharged cured September 29 th.

We had in this instance $n$ very encouraging example of the utility of surgical procedure in $\mathbf{n}$ case of multiple emholic suppuration of hoth kidneys, an nffection which heretofore was considered nbsolutely hopeless. On the other hand, it is very qnestionahle whether the most energetic measures will he of nny use where the multiplicity of suppurative foci virtually amounts to $n$ complete destruction of the orgnn. This condition is comparahle to the infiltrating, diffuse phlegmon of a limh, in which the most thoroughgoing and extensive incision cannot lay open every focus of infection, and where the danger to life can he eliminatcd 
oaly by au ablation of the entire organ. Tbis remark refers to $n$ late stage of the infection. Different, however, is our standpoint when we assume that hy an early nnd extensive incision this very destruction may he prevented. At any rate, it is proper thnt this interesting and important question be submitted to $n$ thorough test. Assuming thnt the rapid extension of the destructive process $\mathrm{cm}$ he modificd and checked by nn early incision, this procedlure assumes $n$ truly conservntive value. The rapidity with which the kidney mny hecome compromised cnn he estimated from the following history :

Chronic cystitis; acute parenchymatous nephritis with miliary abscesses; uephrotomy; nephrectomy; curc.-Mrs. S. S., aged thirty-four years, was admitted December 13, 1896. Fnd bad two children, and stated on ndmission that she had been suffering from painful micturition for two years. Her strangury was so intense thnt occssionnl catheterism was necessary. On Decemher 7 th, shortly after a catheterism performed hy her family physicion, she suddenly felt an intense, cutting pain in her left loin, whicb was followed by a violent chill and high fever. Eacb paroxysm was accompanied by retching and vomiting. The lumbar pain was growing steadily worse, radiating toward the bladder and left tbigh. On ndmission n temperature of $104^{\circ} \mathrm{F}$. was found. A continuous desire to urinate tormeated the patient, even wben the bladder was empty. Her pulse wassmall, very frequent; her integument batbed in perspiration, nnd in the left loin an exquisitely painful tumor could be felt, whicb was overlupped hy the colon, and was evidently tbe left hidaey. During nine bours wbicb preceded tbe operation she voided thirtcca and oae-balf ounces of urine, wbicb was alkaline, bad $\mathrm{n}$ specifio gravity of 1022, contained a trace of albumin, a few pus-corpuscles, but no blood. She was cbloroformed as soon as I had seen her, and the ealarged kidney was exposed. It was observed tbat a considerable quantity of watery serum escaped from the fatty envelope of the kidney, whicb was ædematous. The surfnce of the kidney appenred to be deeply congested. As soon as the capsule was incised tbe purenchyma bulged out. When the cortex was incised no hlood was seen to flow, but turbid, bloody serum was escaping. Several punctures of the kidney were made, until finally n cavity, evidently the pelvis, was found, from which nlso n dark-brown bloody serum was withdrawn. Using tbe needle as $\mathbf{n}$ guide, the pelvis of the bidney was freely incised, the incision penetrating from the convexity. While n finger was dilating the deeper purt of the incision $n$ resistant hand of tissue gave wny. This was followed by extremely profuse arterial hemorrhage, which, however, was easily ebecked by firm plugging vitb iod of orm-gauze. To encourage secretion the kidney was separated everywhere from its fatty envelope, and was surrounded with gauze compresses. Then the wound was dressed.

The only change observed was the disappearance of the acute pain, but retching and the higb fever remained, though not so intense as before the operation. When the dressing was changed on December 14th the nhsence of thnt copious sero-sanguinolent discharge was noted which is seen regularly to follow nephrotomy. Tbe same observation was made duriag the following three weeks. Nineteen and one-half ounces of 
urine were voided on December 15th. It was alkaline, containing few pus-and hlood-corpuseles, $n$ trace of alhumin, and had n specific gravity of 1024 ; strangury uncbanged. These observations madc it extreniely probahle, not only that the secretion of the diseased kidney was remarkably scanty, but also that its ureter was occluded. Otherwise much hlood would have descended to the bladder. On December 20th the deep packings wrere removed from the kidney. Renewed nrterial hemorrhage compelled us to replace thcm immediately. Some pus also escaped, but its souree could not he ascertained. The quantity of urine passed hy the urethra had increased, Decemher 16th, to forty, December 20th, to sixty ounces, nnd its reaction had become acid. No blood was found in it at any time before January 7 th. With continuing fever and vesical pain the condition of the patient became gradually and steadily worse. Several larger and smaller abscesses had broken through into the drainage-chsnnel, and it became evident that the patient would succumb unless the kidney were removed. Accordingly on January 7 th this was done. The day preceding the operation sixty-two ounces of urine were voided, hence wre conclnded that the other kidney was acting in $\mathbf{n}$ satisfactory manner.

During the nephnectomy the following facts were ohserved: the rolume of the kidney had shrunk to about the normal standard. Its parenchyma had a waxy pallor. In the lower portion of the kidney an nbscess containing ahout two ounces of pus was found. Separation of the vessels and ureter ras very difficult on account of thcir extreme shortness. One of the ligatures slipped after the kidney was cut away, and the tremeudous hemorrhage was controlled by a large clamp. The wround was packed nnd treated hy the open method. The patient hore the operation very well. By January 11th there was a marked diminution of the fever noticeable, and the daily quantity of uriue, which had falleo from sixty-tiro ounces to twenty-six ounces after the operation, arose from twenty-eight ounces on Jnnuary 11 th to seventy-one and one-half ounces on January 12 th, which remarkahle rise was undoubtedly induced by copious draughts of water. The urine contained much hlood the day nfter the operation. From this day on recovery went on uninterruptedly. The last ligature came nway on January 29th, and February 4th the larger part of the wound was closed hy secondary suture. At present tbe patient is expecting ber carly discharge. It may be added that the strangury censed immediately after the nephrectomy. The urine is at present acid, abundant, and contrins nothing ahnormal except a slight trace of nlhumin. The pathologicnl report on the specimen is as follows:

Diagnosis. Acute parenchymatous nephritis, with emholic abscesses; incipient purulent nephritis.

Glomeruli partly normal, partly atrophic; in the latter case the capsule is filled witb granular material; the epithelium congested; tbe canaliculi show granular degeneration; nuclei do not accept staining. The epithelium is swollen nnd necrotic; everywhere between the canaliculi round-celled infiltration, without increase of the connective tissue. Tessels appear to be normal, with the exception of the smaller capillaries, wbicb are clogged with $n$ lange number of small cocci, prohably staphylococcus. The cocci become beautifully visible hy staining with Löffler's solution. Inside of tbe cannliculi there are also groups of short rods, which take the Löffler stain. Everywhere in the cortex are small, 
but well-defined agglomerations of degenerated white blood-corpuscles, which can be accepted as miliary nhscesses,

Nephrotomy was performed in this case six days after invasion, but the destructive process was not checked hy it, nor could the infectious material accumulated in the kidney be drained away in an effectual manner. Had nephrotomy heen donc twenty-four or forty-eight bours after invasion, would it have heen otherwise?

Fulminant and fatal case of double ascending gonorrhoic nephritis deserves to he described here on nccount of its rarity:

J. J., nged ten yenrs, ncquired gonorrhoen while crossing from Europe in the steerage of a transatlantic steamer. The disense became manifest on April 30tb, when he arrived. On Mry 15th difficulty of micturition and fever set in. Mny 22d-i e., eight days before his admission to the hospital-violent lumbar pain of both sides was complained of. Three days previous large quantities of pus were voided by the urethra, followed by some blood. After that continuous bigh fever prevailed; the secretion of urine becoming gradually diminished, and finally scanty, On admission, on tbe evening of $\mathrm{May} 30$ th, the followiug facts were observed : the patient somewbat cyanosed, somnolent, covered with perspirntion; his extrenities cold ; temperature $101.4^{\circ} \mathrm{F}$., pulse 130 ; copious purulent discharge from the urethra, from which there escaped at short intervals, involuntarily, bloorly, turbid urine in small quantities; the urine cbarger witb pus, albumin, and blood; alkaline; its specific gravity 1030 . The following morning $I$ found, in addition to the facts just related, botb kidneys perceptibly enlarged and palpable, especially so the rigbt one, which was exquisitely painful to touch. The amount of urine voided during the entire nigbt was eight ounces. In spite of this desperate condition I determined to incise both kidneys. After the administration of a small quantity of chloroform to produce primary stupor, tbe rigbt kidney was rupidly exposed. Its fntty capsule was found very cedematous, the kidney itself enormously enlarged and tense. Wben tbe cortex was deeply inciscd there was no bemorrhage. The parenclyma appeared dusky, almost brown, nnd mottled with a Iarge number of gray spots. It was extremely brittle, discbarging turbid, reddishbrown serum. The same kind of serum escaped from the pelvis. A large drainage-tube was slipped into the opened kidney, and the wound was packed. On account of failing pulse incision of the other kidney was desisted from. The patient rallied from the collapse, hut his previous condition remained unchanged. Tbe amount of the urine continued to diminish, until the suppression became ahsolute. Tbe boy died twenty hours after the operation, with a temperature of $105^{\circ}$ F. The minutes of the post-mortem examination, made by Dr. Mandelbaum, the patbologist, on June 1st, read as follows :

Botb kidneys very much enlarged, especially so tbe right one, which seemed to be increased to double the normal volumc; the left kidney was much congested, containing in its lower portion an abscess which held 4 c.cm. of the pus; the right kidney converted into a mass of innumerahle abscesses varying from the miliary to the size of $\mathbf{n}$ cherry; capsule strongly adherent; the cortex much thickened. In stripping of the capsule i large number of subcapsular nbscesses were exposed; the lower 
half of the kidney occupied hy a large disintegrating clot; the ureters normal, with the exception of the lower tbirds, which are much congested; vesical walls considerahly thickened; vesicnl mucous memhrane cverywhere hemorrhagic; the prostate much enlarged, strongly congested, and containing a nearly empty abscess-cavity, which still held $2 \mathrm{c.cm}$. of pus. Slide-preparations of pus gained from the kidneys contained multitudes of staplyylococci and gonococci. The hlood-serum and serum-agar cultures of the same pus yielded colonies of gonococcus and staphylococcus alhus. The pus from the prostate, however, yielded only staphyloeoccus alhus. Cultures made from the uretliral diseharge remained sterile, prohably hecause they were taken shortly nfter thc escape of some urine. Milieroscopic sectioas of hoth kidneys gave evidence of unmistakahle pyeloncphritis, and shorsed luxuriant colonies of gonococcus and staphylococcus hy means of Löffler's solutioa. Gonococci were in evcry instance decolorized when trented hy Gram's stain.

Ia the presence of such an extraordinary invasion of both kidneys little can he expccted from any therapy instituted at a late period of the disense. I wish to emphasize the opinion that when both kidneys are attacked simultaneously in $n$ very virulent manner the indication for eaergetic actioa seems to he most urgeat, and that much more ought to he doae than heretofore in this field, searcely cultirated hy any surgeon. The same indication presented itself in another case during the period of time comprised ia this paper, but my urgent wish to interfere was frustrated hy the resistance of the patient:

Repeated nephrotony for pyonephrosis; relapse; nephrectomy; suppression; dealh.-J. W., aged thirty.five years, had heen opcrated ou by me for calculous pyoaephrosis in May, 1893, at the Gcrman Hospital. Two stones were removed, and the patient was discharged cured. On Fehruary 23, 1895, the samc operation was performed a second timo at Mount Sinai Hospital hy Dr. Lilienthal, who nlso evacuated much pus and removed one stone from the kidney. The patient again recovered, and the wound healed. The patient was rendmitted February 24, 1896 . Hc stated that his old pains had recurred in the lumhar region, with high fever, chills, and vomiting. Strangury and augmenting pain drove him to the hospital, where a considernhle tumor was found occupyiag the left loin, with a temperature of $100.6^{\circ} \mathrm{F}$., nnd alkaline urine, which contained much alhumin, pus, phosphates, nnd hyaline casts. The daily quantity of urine was fifty-one ounces. The right kidney could not he felt, nor was deep pressure exerted upon the right loin painful. Fehruary 27 th the bladder was emptied and irrigated, preparatory to a cystoscopic examination, which, however, could not he carried out on necount of the oecurrenee of a severe chill. March 2d, under ehloroform, the old scar being ineised, the much-enlarged left kidney was cxposed and opened. It consisted of $\boldsymbol{n}$ thin-walled hig, composed of $\mathbf{a}$ numher of communicating cavities distended hy pus, many of these cavities still containing stones. As the organ had hecome manifestly uscless it was immediately removed. Hemorrhage was very modernte, and the patient rallied well from the nperation. During the following night very littlc urine was voided (eleven ounces in sixteen hours), becoming more and more scanty. The patient was npparently failing. 
His pulse was very rapid ; the temperature $104.6^{\circ} \mathrm{F}$; t the skin covered with a clammy perspiration. My proposition to relieve the right kidney by a free incision was firmly declined, and the patient died March 4th in a comatose condition. No post-mortem could be had, but the right kidney was vithdrasn through the existing wound, and was found in a state of purulent pyelonephritis, which seems to have existed for some time.

It is proper for me to make this remark that, had I heen content with simply incising for a third time the lcft kidney, the patient's life would have been prohahly proloaged.

How little can be cxpected from simple nephrotomy in the presencc of a multiple suppuration of the kidney can be seen from the following case :

Tumor of the kidney with pyuria; nephrotomy and evacuation of five renal abscesses, each containing a stone; closure of the uound; recurrence; nephrectomy of the calculous kidney; cure.-MIrs. J. V., aged forty years, multipara, admitted June 8,1896, stating that she had suffered from persistent hxmaturia fivc years ago, which, however, ceased spontaneously. A year ago she had sharp renal colic, accompanied by fever and vomiting. Sbortly after this pus ras detected in the urine. Micturition was never painful. Since four months continuous pyuria and noticeable emaciatiou existed. Dr. Alfred Mleyer found a lumbar tumor, and sent tho patient to me. On admission a large, dense, non-fiucluating tumor was found in the right loin, which protruded into tbe hypochondrium, displacing the colon downward and fortrard. The urine was abundant, acid, had a specific gravity of 1016, and contained large quantities of pus and some albumin. June 10th, through the cystoscope a normal, pale vesical mucous memhrane was seen. Furthermore, it was olserved that on gentle massage of the right groin a cylindrical plug of pus escaped from the right ureter, the orifice of which appeared much congested. The left ureter appeared normal. Into this a catheter was introduced by means of Kelly's procedure. Sixteen grammes of urine were collected, that contained a few pus-corpuscles and traces of albumin. Hence it was concluded that the left kidney, though not perfectly sound, was not seriously involved.

June 15 th the right lidney was exposed and freely incised. From the pelvis and from'four calices large quantities of pus and several irregular shaped uratic stones were removed. The kidney and wound were drained in the usual fashion and dressed. Little reaction followed. The secretion diminished rapidly, and patient was discharged July 18th with a nenrly closed wound. Her general condition had improved noticeahly. October 7 th she presented herself again, reporting that the wound, which had heen closed for sereral weeks, had reopened a wcek ago, discharging a large quantity of pns. I found the lumbar tumor smaller tban it was before the first operation, painless to touch; the general condition of the patient was very good, her urine acid and abundant, but containing much pus. I advised the removal of the kidney, which was done Octoher 22,1896 , without accident. The kidney was found to contain six more ahscesses, ench hurboring a stone. The renal parenchyma looked waxy, and was very much shrunken. By Octoher 27th the urine hecame nearly normal, though still containing microscopical 
quantities of pus. Norember 20th the mass-ligature of tbe pedicle came nwny, and Decemher 15th the patient was dischnrged, cured.

Tbe presence of morbid cbanges in the otber kidney should not prevent nephrectomy of a totally disorganised organ. On the contrary, the removal of such a pus-hag as was encountered in this case eliminates a continuous menace to tbe other moderately diseased kidney.

Resembling in many respects tbe preceding one, the following case was nevertbeless much more serious, on account of the extremc marasm caused by a renal suppuration of ten years' standing :

Calculous pyelonephritis of the right side; cystoscopy; nephrectomy; cure.-E. W. A., aged tbirty-eight years, merchant, was admitted October 13,1896, having come from the South. He stated that twelve ycars ago internal uretbrotomy bad been performed for rebellious glcet and stricture. This wns followed by an acutc cystitis, which had persisted ever since that time. He suffered for ten yenrs, more or less, from periodical attacks of screre renal colic of the right side, which were nccompanied by chills and hloody urination. In spite of a ravenous appetite tbc patient had emaciated to $n$ skeleton. Since ten weeks bis urine had become putrid, and from that time on continuous fever, frcqueat chills, nigbt-sweats, and incessant lumbar pain, radiating toward the bladder nnd the right testicle, were present. Urination wos very frequent. The pbysical examiantion showed excessive emaciation and light anasarca of the feet; otbcrwise normal conditions; an accelernted pulse of good quality. In tbe right loin n largc, sensitive, resistant tumor could be felt, wbicb descended to the level of tbe navel, and cxtended to the median line. The urine wro foul, but acid, containing mucb pus, somo blood, and very large quantities of detritus; its daily quantity was about fifty ounces; the temperature $100.2^{\circ} \mathrm{F}$. in the morning, with regular evening exacerhation. Octoher 14 th cystoscopy was done. The trigonum was found to be moderately congested, especially around tbe orifice of the right ureter, from which a solid plug of pus wns seeu escaping. From the left ureter clear urine was seen escaping at short intervals. Catheterization of this ureter was not attempted. The left kidney could not be palpated. The assumption was fairly justified that the left hidney was sound. October 15, 1896, the patient being chloroformed, the tumor wns cxposed and ensily separated from its lateral adlesions. It rcpresented a thin-walled sac from which the aspirator removed foul pus, and within which n number of stones could he distinctly felt. The cortex appeared waxy. A mass-ligature was placed around the pedicle and tbe organ was ahlated. The wound was dressed in the usual manner. During the first twenty-four bours following the operation fifty ounces of u rine were voided, which was nearly clear. It had a high specific gravity, contrining a small quantity of pus and a little hlood. From Octoher 18 th the temperature hecame normal. The urine continued to be abundant, and the patient's general condition, aided by his enormous appetite, was rapidly improved, so that on November 15th he could return to bis home cured, having gained since tbe operation tbirty-four pounds in weight.

Concluding Resarks. The surgical principle, to afford timely relief from tension, and early to evacuate nfter nn early diagnosis, made 
ia the presenee of ncute suppurative processes threatening the integrity of an organ, must find unreserved application ia suppuratioas of the kidney. The earlier such measures are taken the more they deserve to be called truly conservative-that is, directed toward the preservatioa of the funetiosal ability of the viscus. Nephrotomy done in the early stages of renal suppuration is n safe procedure, and ought to be done much ofteucr than heretofore, the indicntion beiag based upon the prescuce of suppurative fever, a renal tumor, and especially upos the voiding of $\mathfrak{a}$ decreasing daily quantity of uriae.

Secoudly. As far as the iadication is coacerned for the performance of nephrotomy is the preserce of acute non-suppurative forms of aephritis, Reginald Harrisoa stroagly recommeads early interference whenever, in the preseace of an infection, albuminuria and appreeiable paiaful reanl intumescence can be demonstrated, from which the presence of iacreased renal tensioa can be deduced. He published ia the isiue of the Lancet of Jaauary 4, 1896, three successful cases of aephrotomy performed, respectively, in a cose of scarlatianal nephritis, in one caused by influenza, and ia another one following exposure to reather. These suggestive faets are mentioned here only to serve as a stimulus to further endeavor.

\section{Neoplasms of the Kidney.}

During the period comprised within the limits of this paper the kidney was twice successfully removed for neoplasms. Unfortunately in oan of the cases relapse followed:

CAsE I. Alveolar sarcoma of the right kidney; extirpation; cure; relapse.-D. G., aged five and a half years, was admitted June 13, 1896, to IIount Siuni Hospital. Her mother stated that the ehild had commeaced to complain of right lumbar pain six weeks before, and that a peculiar lardaess could be felt in the loin. No difficnlty or pain in uriantion was observed, but the patient became pallid and lost flesh. Oa admission a large, smooth tumor could be felt occupying the right loin and hypochondrium, extending downward to the crest of the ilium, and projecting the width of fonr fingers heyoad the median line. It was scarcely movalle, and by inflation the colon was found to be displaced far downward and to the left side. The tumor could not he differeatiated by percussion from the liver. The urise was ahsolutely normal, likewise all the other organs. June 19th the patient was chloroformed and the posterior aspect of the tumor was exposed hy an iacisioa beginaing near the margia of the quadratus lumhorum, and extendiag in an oblique direction downward and forward four inches beyond the median line of the albdomen. The peritoneal cavity was inmedintely opened and the collapsed intestines were packed away under hot towels. After this ny first endenvor was to expose the reanl vessels, as from their early occlusion I expected a considernhle diminution of the otherwise dangerous and profuse hemorrhage. Accordingly, the peritoseum was stripped up from the kidney until the ureter and renal vessels were exposed. They were cut through between a double 
ligature. A large portion of the peritoneum was so closely ndherent to the mass that it had to be sacrificed. The most difficult part of the operation consisted in the sepnration of the upper portions of the mass from the under surface of the liver. A number of lnge veins communicating with the liver were torn through, nnd hled profusely. Arteryforceps being innplicable, the bleeding surface was covered with an iodoform-gauze pncking, by which the hemorrhnge was perfectly controlled. After the kidney had been removed an nppalling cavity lny exposed, in the hottom of which the venn cavn could he seen hnred to the length of six inches. An aftuent vein of the size of a crow-quill had been torn out of the venn cnva. The resultant defect was closed hy $n$ continuous lateral catgut suture of the rein-wnll. While $I$ was rapidly closing the peritoneal defect by a continuous catgut suture, nnd while tbe nhdominnl portion of the external wound was being closed by n number of button sutures, Dr. Lilientbul infused 1000 grammes of normal saline solution, this bnving hecome necessary by $n$ threatening collnpse. The wound was plugged with ahsorhent gauze brought out near the posterior nngle, nad vas dressed. The pntient was hrougbt to bed with $\mathrm{n}$ thready pulse. Repented nttncks of collnpse required constnnt vigilnnce nnd renewed energetic stimulation. During this period of depression, lasting until June 21st, the quantity of urine voided was decidedly below the normal, containing nlbumin, but no blood.

Stools passed involuntarily, and the child's condition remained critical until July 15th. Tbe apathy and depression gradually disnppeared. In spite of the extensive nbdominal invasion the child took and retnined considerable qunntities of strongly stimulnting liquid food, nnd to this circumstance is to be ascrihed her recovery. The sutured parts bealed by the first intention. The lange cavity contracted rapidly, and the patient's general condition improved visibly, so tbnt sbe could be discharged cured September 6 th. Unfortunately, $n$ relapse became manifest toward the end of Novemher, when the patient was presented to me with a rapidly growing tumor, occupying the lower surface of the liver. It was inoperable. She died in December. The pathologist-reported that the tumor was an alveolar sarcoma.

The remornl of this very lnrge and, in its upper circumference, closely ndherent tumor became only possible through tbe ndoption of the plnn of exposing nnd securing the renal vessels nt the heginning of tbe operation. The principle of first securing the important vessels holding close relations to $n$ large tumor, hefore nttempting its extirpntion, was first promulgated hy Langenheck.

Case II. Chronic pyelitis; endothelioma of the right, pyelitic hidney; frequent homaturia; cystoscopy; extirpation; cure.-I. D., peddler, aged forty-four years, hnd been suffering for eight months from frequent exhnusting hamaturia, which had not depended upon nny form of traumatism. An operation was proposed to him in Octoher by Dr. Fluhrer, but was declined. On readmission, January 19, 1897, I found in the right loin of the nnamic nnd somewhat emaciated man $n$ movnble nodular tumor, wbicb was not painful to touch, and did not fluctuate. All other organs nppeared normal. The urine, voided in sufficient quantity, was acid, had n specific gravity of 1021, and contained mucb pus, $n$ few 
blood-corpuscles, and much detritus imbedded ia glairy mucus. The left kidaey could not he felt. January $22 \mathrm{~d}$ eystoscopy was done. The vesical mucous membraae appenred aormal. Oa massage coaducted along the course of the right ureter the exit of a cyliadrical plug of consistent pus could be observed from the orifice of the right ureter. The left urcter appeared normal, and the escape from it of clear lig.jil was repeatedly seen. The rermicular muterial gaiaed from the right urcter came nwiay through a cutheter passed af ter the cystoseopy, and consisted of pus, mucus, nad hlood. January 26 th, the pntient beiug anasthetized, the diseased kidney was easily removed through the usunl oblique incision. The vessels of the pedicle and ureter were sepnrately ticd, and most of the wouad was closed hy suture. The day after the operation the urine showed no traces of pus, hut contaiaed a few hloodcorpuscles, and was abuadaut. Healing was uaeveatful, and the patient was discharged cured, February 28 th. The pathologist's report oa this specimea was: proaounced alveolar arrangement of the sarcomatous elemeats, which clearly derived their origin from the endothelium of the smaller hloodvessels of the kidney.

Techincal Resrarks. Uniform preference was given to an uhlique iacision hegianing from the twelfth rib aear the margin of the quadratus and extcadiag downwurd and forward well into the ahdominal wall, the length of the incision depending upoa the size of the tumor to he dealt with. Simoa's vertical incision yields much less space, and, in the case of large tumors, must he supplemeated hy oae or more transversely placed incisions. Exteading the oblique incision wcll forrard has the advantage that the reflection of the peritoneum is readily found, and its nccidental injury can be easily avoided. Furthermore, by following the guidance of the peritoneum the ureter is found without difficulty, and $\mathrm{n}$ kidney oceupying a higb position, and hidden by the lower rihs, can he exposed and made accessihle witbout additional resection of the rihs. The renal vessels can also be readily secured, which step commends itself as the initiatory oae in the extirpation of large renal tumors. The nhdomiaal muscles should be always reunited in the anterior two-thirds of the wound hy huttoa sutures. Where contamination hy the accidental escape of pus is a ot present, and the ureter nnd ressels were tied sepnrately with catgut, the entire wound can he closed hy sutures, with the exception of the posterior angle, which is to he left open for the almissioa of a lnrge drainngetuhe. Sbould the wouad become coataminated hy pus, it is safe to employ $n$ thoroughgoing and careful pncking of nll recesses with ahsorheat gauze. This can he witbdrawn on the fourth or fifth day. Should the wound then he found clean and sweet, the employment of a secondary suture will materinlly shorten the duration of the healing-process. Should it he aecessary to apply $n$ mass-ligature to the pedicle of the kidaey, a solid, cylindrical hnd of ruhber, nhout one-sixth of an inch ia diameter, will he fouad very convenient nnd safe. It will never 
slip, and will cut through much sooner than n silk ligature. Patients should he encouraged to leave the bed as soon as possible.

\begin{tabular}{|c|c|c|}
\hline \multicolumn{3}{|c|}{ Statistics. } \\
\hline Plastic of the & & \\
\hline Extirpation of & & \\
\hline Nephrotomy & & \\
\hline Nephrcetomy & • & \\
\hline Of these & & \\
\hline Improved & & \\
\hline Died & & \\
\hline
\end{tabular}

\section{THE RELATIONSHIP OF OTOLOGY TO GENERAL MEDICINE.'}

By Grarexce J. Bhake, Mr.D., PROFESOR OF OTOLOOY IX IUAVARO ENITERSTY FELOW OF THE AMERTCAN OTOLOGICAL BOGETY.

SoMrEweat more than twenty-five years ago one of the first distinctly special practitioners in this country made n statement in open meeting to the effect that geneml practitioners were to he considercd as the rank nnd file, and specialists as the officers nnd staff of that army whose business it is to fight, to conquer, and to limit the ravages of disense. It is needless to say that this proposition met with but little favor from his heares, and, notwithstanding the growth of specialism and the division of the work done by the medical profession into parts, having apparently often but very slight relationship to each other, it would meet with no more favor to-day. At the time when it was first made specinlism in medicine was $n$ new, to many $n$ dreaded, and to some an abhorrent thing. The general practice of medicine left the more minute investigation of many organs and their diseases untouched; hacteriology was not, and aseptic surgery had not yet come to point the shorter patl to many a long-sought goal and cut the knot of many a medical prohlem.

With the experience of a quarter of $n$ century, the simile between the medical profession and an army can he only justly used hy comparing that arny to a hrotherhood, the members of which have each nnd all equal, though different, functions, and if the general practitioner is to be classed with the rank and file, the specialist is to he regarded, not as in any way a superior officer, hut as one of that rank nnd file sent out on special service; for, everywhere, the men who, with the foundation of the general study of medicine, nnd, still better, in nddition, the practical study of general mediciue as their hase, go forward in any particular

\footnotetext{
I Rend at the Congress of Ameriean Physletans and Surgeons, Washington, May, 1897.
} 
line of investigation, may be regarded as skirmishers sent in advance, whose duty it is; first of all, to observe, and, secondly, to report back to the main body tbe result of their observations, nnd tbus to indieate the lines oa which the main hody may advantageously proceed. It stands to reason, therefore, that the specinlist, in whatever line bis duty may take him, must be not only an observer, but in some way or other, and to a greater or less degree, $n$ tencher; and the extent to whicb these functions lave been fulfilled, and these relationships of the interdependent parts of the medical community bave been developed in the last twenty-five years, it is interesting to observe.

The establishment of the nine special societies which, in addition to the five others of more general purpose, make this august Association, is a striking evidence of the fact that within the period mentioned the growth of scicntific medicine and the enlargement of its field of observation hnve so increased as to make it impossihle for any one student to cover completely and adequately the whole ground; and we realize that it is, as always, the study of the infinitely little which establishes the immensurahly great.

Thirty years ago, with few exceptions, there was not a sufficiently large number of medical men engaged in any special hranch of research to form a society. The first of the several special societies forning the present Congress of American Physicians and Surgeons was founded in 1864 , and the others followed in the order given in the circular of this Congress.

Buried deep beaeatb tho surface, approachable only through n narrow and somewhat tortuous canal, containing within itself an example of almost cvery bistological structure to he found within the human hody, the luman ear had long been $n$ favorite study of tbose older anatomists whose miuute and painstakiag investigations and whose debeacy of research were in kceping with the work of tbeir artist contemporaries. As always, the anntomist lays the foundation-stone; and to Meckel, Valsalva, Eustachius, and Corti we are indehted for that knowledge which has made the study of diseases of the ear, both in itself and in its relation to general mediciae, one of the most fascinating of its kind. For not only does the inaccessibibty of the organ require, on tbe one hand, trained manipulation in the surgical trentment of its disenses, but, oa the other band, the reflex relationsbip of tbe ear to otber organs in the body, its visihle and sometimes elucidative participation in other diseases, and its multiple office as an organ of hearing, as a peripheral organ of equilihration, and also as a supplemental organ of space-perception, afford wide opportunities for that theoretical coajecture which is the appetite of research and tbe stimulus to scientific nutrition.

The mental processes wbicb lead to effective results are always slow and concentrative, and in tbe brotberhood of scientific researcb some 